
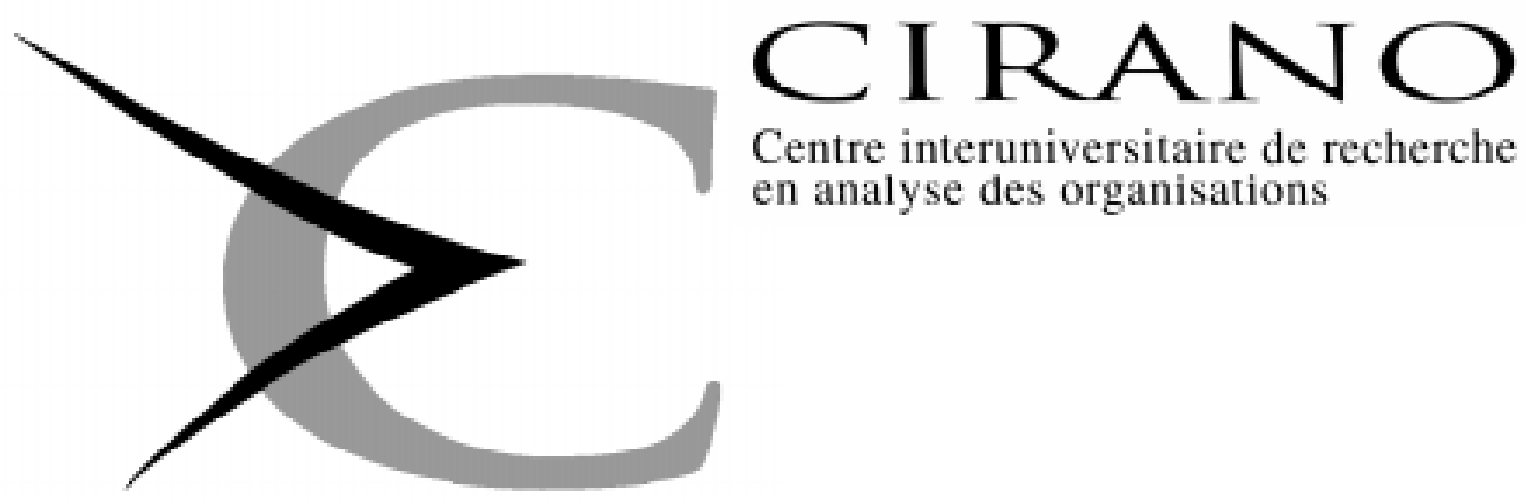

Centre interuniversitaire de recherche en analyse des organisations

Série Scientifique

Scientific Series

97s-37

A General Equilibrium

Analysis of the Evolution of the

Canadian Service Productivity

Pierre Mohnen, Thijs ten Raa

Montréal

Novembre 1997 


\section{CIRANO}

Le CIRANO est une corporation privée à but non lucratif constituée en vertu de la Loi des compagnies du Québec. Le financement de son infrastructure et de ses activités de recherche provient des cotisations de ses organisations-membres, d'une subvention d'infrastructure du ministère de l'Industrie, du Commerce, de la Science et de la Technologie, de même que des subventions et mandats obtenus par ses équipes de recherche. La Série Scientifique est la réalisation d'une des missions que s'est données le CIRANO, soit de développer l'analyse scientifique des organisations et des comportements stratégiques.

CIRANO is a private non-profit organization incorporated under the Québec Companies Act. Its infrastructure and research activities are funded through fees paid by member organizations, an infrastructure grant from the Ministère de l'Industrie, du Commerce, de la Science et de la Technologie, and grants and research mandates obtained by its research teams. The Scientific Series fulfils one of the missions of CIRANO: to develop the scientific analysis of organizations and strategic behaviour.

\section{Les organisations-partenaires / The Partner Organizations}

-École des Hautes Études Commerciales

-École Polytechnique

-McGill University

-Université de Montréal

-Université du Québec à Montréal

-Université Laval

-MEQ

-MICST

-Avenor

-Banque Nationale du Canada

-Bell Québec

-Caisse de dépôt et placement du Québec

-Fédération des caisses populaires Desjardins de Montréal et de l'Ouest-du-Québec -Hydro-Québec

-Raymond, Chabot, Martin, Paré

-Scetauroute

-Société d'électrolyse et de chimie Alcan Ltée

-Téléglobe Canada

-Ville de Montréal

Ce document est publié dans l'intention de rendre accessibles les résultats préliminaires de la recherche effectuée au CIRANO, afin de susciter des échanges et des suggestions. Les idées et les opinions émises sont sous l'unique responsabilité des auteurs, et ne représentent pas nécessairement les positions du CIRANO ou de ses partenaires.

This paper presents preliminary research carried out at CIRANO and aims to encourage discussion and comment. The observations and viewpoints expressed are the sole responsibility of the authors. They do not necessarily represent positions of CIRANO or its partners.

ISSN 1198-8177 


\title{
A general Equilibrium Analysis of the Evolution of the Canadian Service Productivity*
}

\author{
Pierre Mohnen ${ }^{\dagger}$, Thijs ten Raa
}

Résumé / Abstract

\begin{abstract}
Dans cet article, nous mesurons les productivités factorielles (et dès lors la croissance de la productivité totale des facteurs) à partir des principes essentiels d'une économie (les ressources, les préférences et la technologie) sans avoir recours aux prix du marché. Les productivités factorielles sont les multiplicateurs de Lagrange d'un programme linéaire qui maximise la demande finale domestique sous les contraintes sectorielles, les contraintes de ressources et la contrainte de la balance commerciale. Nous appliquons le modèle aux données de l'économie canadienne de 1962 à 1991. Les données ne concordent pas avec l'hypothèse traditionnelle selon laquelle les services ralentissent la croissance de la productivité.

This paper measures factor productivities (and hence total factor productivity growth) directly on the basis of the fundamentals of the economy (endowments, preferences and technology), without recourse to market prices. The factor productivities are the Lagrange multipliers of a linear program maximizing domestic final demand subject to material balances, endowment constraints, and a balance of payments constraint. The model is applied to the data of the Canadian economy from 1962 to 1991. The commonly held view that services are dragging down the whole economy does not stand the facts.
\end{abstract}

Mots Clés : $\quad$ Productivité, programmation linéaire, Canada

Keywords : $\quad$ Productivity, linear programming, Canada

JEL : C61, C67, D24, O47, O51

\footnotetext{
* Corresponding Author: Pierre Mohnen, CIRANO, 2020 University Street, 25th floor, Montréal, Qc, Canada H3A 2A5 Tel: (514) 985-4018 Fax: (514) 985-4039 e-mail: mohnenp@ cirano.umontreal.ca We thank Nathalie Viennot and Sofiane Ghali for their dedicated research assistance and René Durand, Jean-Pierre Maynard, Ronald Rioux and Bart van Ark for their precious cooperation in constructing the data. We are grateful to Carl Sonnen and to the participants of the Service Sector Productivity and the Productivity Paradox preconference for their helpful comments. We acknowledge the financial support of the Social Sciences and Humanities Research Council of Canada.

${ }^{\dagger}$ Université du Québec à Montréal and CIRANO

‡ Tilburg University
} 


\section{Introduction}

The measurement of total factor productivity (TFP)-growth constitutes a conceptual puzzle. It involves the use of wage and rental rates to construct an input aggregate. The growth rate of the latter is compared with the growth rate of output. When output grows faster than input, there is productivity growth, room for increases in factor rewards. Indeed, estimates of productivity growth are used to define the 'room' in collective wage bargaining. However, since the underlying TFP measure hinges on wage and rental rates, there is some circularity in the reasoning.

The puzzle is resolved for perfectly competitive economies. In such economies factor inputs are rewarded according to their marginal productivities. TFP can be conceived as the sum of these marginal productivities taken over all factor inputs. The consequent growth rate agrees with the so called Solow residual measure of TFP-growth. Jorgenson and Griliches (1967) and Solow (1957) have shown the equivalence with the shift of the production possibility frontier. The trouble is, however, that observed economies are not perfectly competitive. They are not even on their production possibility frontiers. If we nonetheless stick to the conventional measures of TFP-growth, employing observed value shares for labor and capital, it is not clear what we get. The residual no longer isolates technical change effects, but also captures variations of the economy about the competitive benchmark, such as changes in market power, returns to scale or the business cycle. The approach of the literature is to correct the Solow residual for those effects, using information on the degrees that the economy departs from the competitive benchmark (Lerner index, returns-to-scale index or utilization rates) and modifying the formula for the residual (Hall, 1990).

Rather than trying to get a handle on the various departures from perfect competition or refining Solow residual expressions by means of inference, this paper attempts to measure factor productivities directly on the basis

of the fundamentals of the economy, without recourse to market deriva- 
tives, such as factor shares, in the use of weights. The fundamentals are the usual ones: endowments, technology, and preferences. Endowments are represented by a labor force and stocks of capital. Technology is given by the combined inputs and outputs of the sectors of the economy. Preferences are reflected by the pattern of domestic final demand. All the information can be extracted from input and output tables in real terms, that is constant prices. The productivities are determined as follows. We maximize the level of domestic consumption subject to material balances and endowment constraints. Now, as is known from the theory of mathematical programming, the Lagrange multipliers associated with the endowment constraints measure the marginal productivities of labor and capital: the consumption increments per units of additional labor or capital. In economics, these Lagrange multipliers are shadow prices that would reign under idealized conditions of perfect competition. We declare these shadow prices to be the factor productivities.

Services have long ago relegated manufacturing to second rank in the importance of an economy's total activity. It is often argued that services suffer from the Baumol disease. More and more resources are devoted to services, where productivity gains are limited. The whole economy thus drifts to a lower productivity performance. Can the slowdown in total factor productivity that we have experienced since the mid-seventies be ascribed to the increasing importance of services, or do we instead observe an improvement of productivity in the services sectors by way of learning-by-doing or specialization? We feel that such questions are best answered within a general equilibrium analysis of the whole economy, i.e. a structural view of the whole economy. Our approach does not belong to the class of general equilibrium models, which model supply and demand functions and aim at finding prices which sustain observed data as equilibrium outcomes. Our position is to start from the fundamentals of the economy (technology, endowments and preferences), to establish the production frontier and its shift over time, and to compute competitive prices which could sustain that frontier. 
The paper is organized as follows. Factor productivities and TFP are defined by means of a linear program in the next section. In section 3 we present the data of the Canadian economy from 1962 to 1991. In section 4 we present our results. The last section concludes.

\section{Productivities}

We push the economy to its frontier by maximization of the level of domestic final demand, which excludes trade by definition. Exports and imports are endogenous, controled by the balance of payments. We make no distinction between competitive and non-competitive imports. (The latter are indicated by zeros in the make table.)

Domestic final demand comprises consumption and investment. Investment is merely a means to advance consumption, albeit in the future. We include it in the objective function to account for future consumption. In fact, Weitzman (1976) shows that for competitive economies domestic final demand measures the present discounted value of future consumption.

Productivity growth will be defined as the measure of the shift of the frontier (see figure 1). Instead of comparing observations of the economy in subsequent periods (represented by the dots), we will compare the projections on the respective frontiers (the arrows).

We normalize the level of domestic final demand using base year prices,

$e^{\top}$ for commodities and $w^{0}$ for non-business labor. The primal program reads 


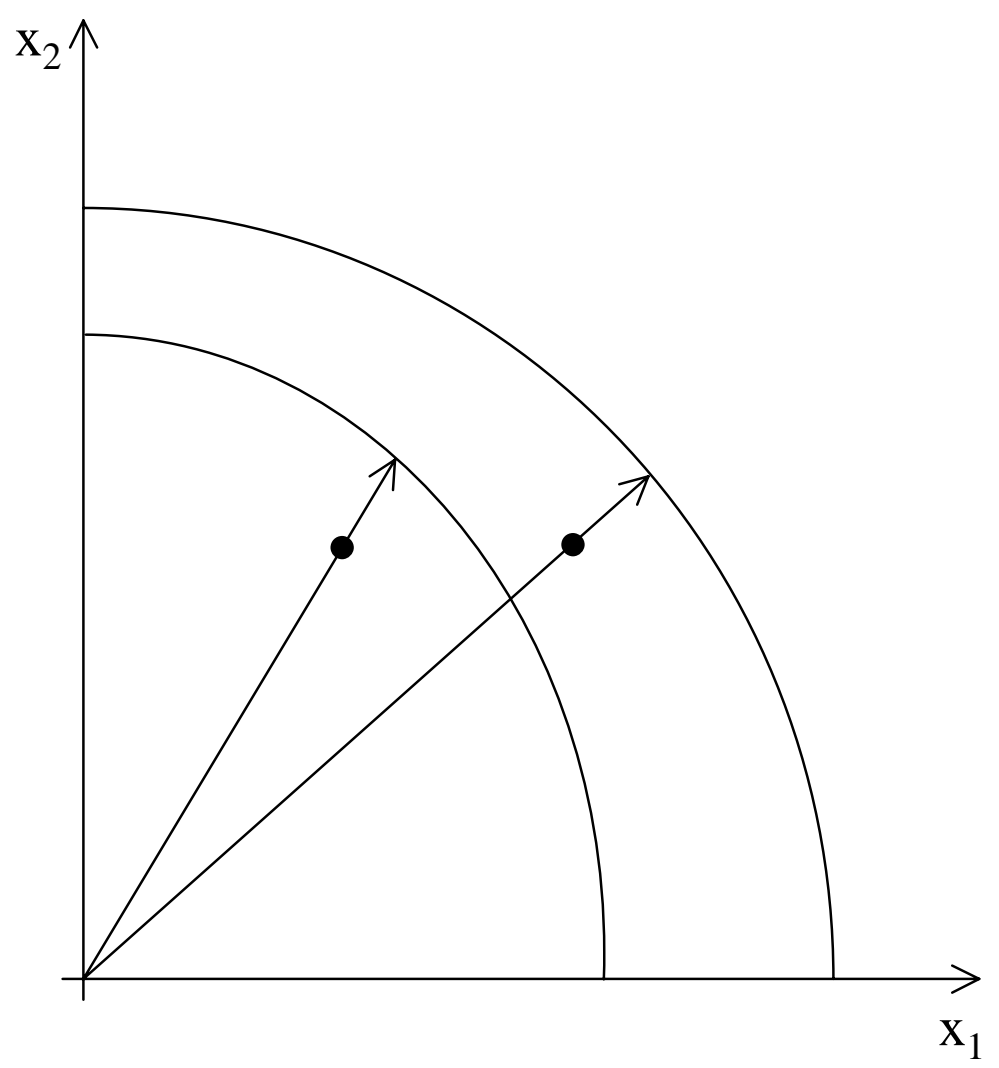

Fig. 1 


$$
\begin{aligned}
& \max _{s, c, g}\left(e^{\top} f+w^{0} l\right) c \text { subject to } \\
&\left(V^{\top}-U\right) s \geq f c+J g=: F \\
& c_{j} K_{j} s_{j} \leq K_{j} \\
& L s+l c \leq N \\
&-\pi g \leq-\pi g^{t}=: D \\
& s \geq 0
\end{aligned}
$$

Here the variables and parameters are the following [with dimensions in brackets].

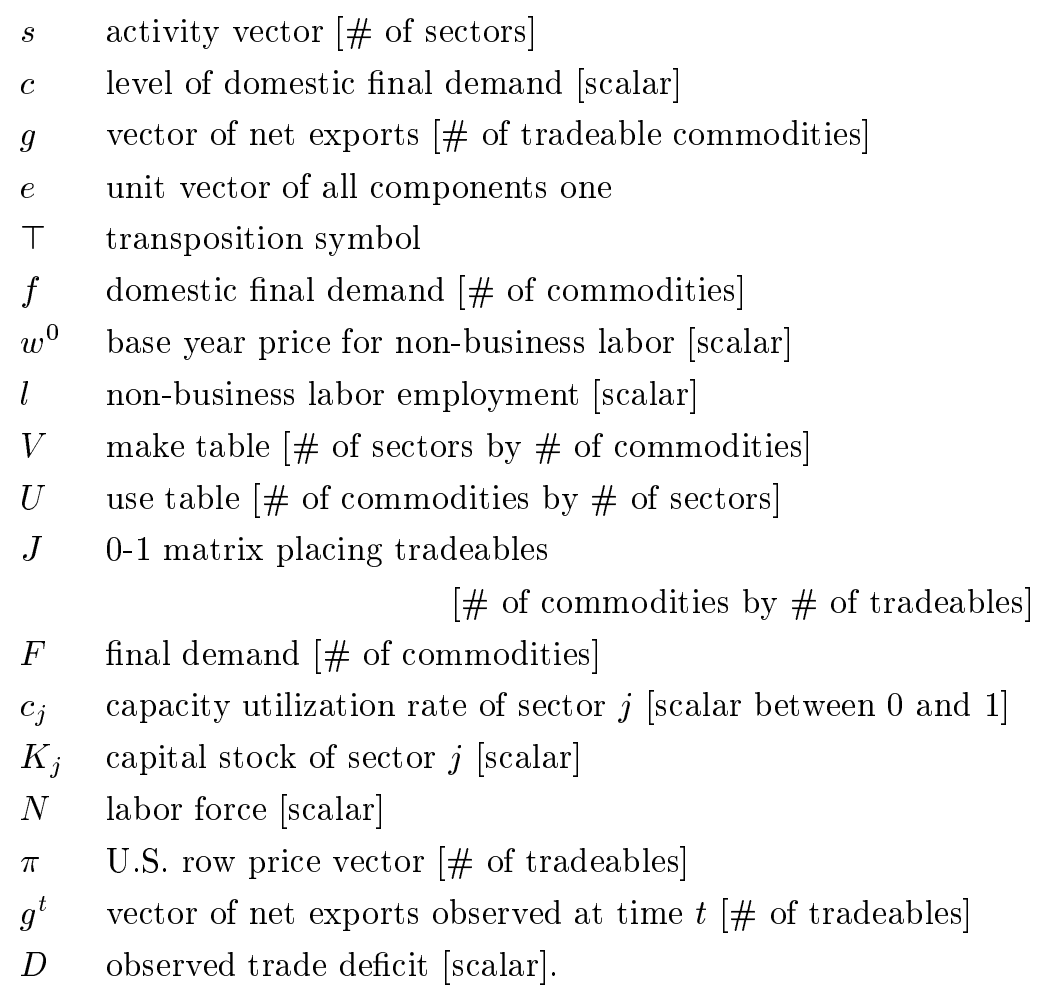

Productivities are not measured using market prices, but are determined by the dual program, which, as is well known, solves for the Lagrange multipliers of the primal program. These measure the marginal products of the objective value with respect to the constraining entities, unlike 
observed factor rewards with all their distortions. The dual program reads

$$
\begin{array}{rl}
\min _{p, r, w, \varepsilon \geq 0} & r K+w N+\varepsilon D \text { subject to } \\
p\left(V^{\top}-U\right) & \leq r \hat{c} \hat{K}+w L \\
p f+w l & =e^{\top} f+w^{0} l \\
p J & =\varepsilon \pi
\end{array}
$$

The variables in the dual program are shadow prices: $p$ of commodities, $r$ of capital (\# of sectors), $w$ of labor and $\varepsilon$ of foreign debt (the exchange rate). Since the commodity constraint in the primal program has a zero bound, $p$ does not show in the objective function of the dual program. $p$ is normalized by the second dual constraint, essentially about unity. It cannot transform nominal price vector $e^{\top}$ into a real one. In other words, it is no device to measure real output.

We now introduce the concept of productivity growth. Since labor productivity is the Lagrange multiplier or shadow price associated with the labor constraint, $w$, labor productivity growth is the growth of $w$, $\dot{w}=d w / d t$. Similarly, $r$ is the vector of marginal productivities for each sectoral capital stock and $\varepsilon$ the marginal productivity of the trade deficit. ${ }^{1}$ Total factor productivity (TFP)-growth is obtained by summing all factor productivity growth figures over endowments, $\dot{r} K+\dot{w} N+\dot{\varepsilon} D$, and normalizing by the level of productivity, $r K+w N+\varepsilon D$. Formally,

Definition. TFP-growth $=(\dot{r} K+\dot{w} N+\dot{\varepsilon} D) /(r K+w N+\varepsilon D)$.

Remark. Replacement of $(f, l)$ by $(\lambda f, \lambda l)$ in the primal program with $\lambda>0$ yields solution $(s, c / \lambda, g)$. The value of the objective function is

\footnotetext{
${ }^{1}$ In fact, there is also a non-business capital stock. Its value enters the objective function. In principle, its level constrains the expansion of domestic final demand. In practice, the capital constraint in the non-business sector is never binding at reasonable rates of capacity utilization, and hence its shadow price is zero. For notational simplicity, we have not included the non-business capital stock in the formulation of the program.
} 
not affected. By the main theorem of linear programming, $r K+w N+\varepsilon D$ is not either. In fact, the productivities are unaffected, as is, by extension, TFP-growth. The replacement does affect the commodity prices, as to preserve the identity between the national product and the national income, which we present next.

Measures. This straightforward definition of TFP-growth is now related to the commonly used Solow residual. By the main theorem of linear programming, substituting the price normalization equation,

$$
p f c+w l c=r K+w N+\varepsilon D .
$$

There are two consequences. First, by complementary slackness between $w$ and the $N$-constraint, as well as between $\varepsilon$ and the $D$-constraint using the price equation for tradeables,

$$
p F-p J g+w l c=r K+w L s+w l c-p J g .
$$

Adding the value of net exports and subtracting non-business labor income,

$$
p F=r K+w L s,
$$

the macro-economic identity of the national product and national income (excluding non-business labor income from either side). Changes in the units of measurement for the commodities, as involved with the replacement of real by nominal data, affect $\mathrm{p}$ and $\mathrm{F}$, but not their product.

The second consequence obtains by total differentiation:

$$
\text { TFP-growth }=\left[(p f c+w l c)^{\cdot}-r \dot{K}-w \dot{N}-\varepsilon \dot{D}\right] /(p f c+w l c) .
$$

To establish the link with the Solow residual, focus on the numerator, 


$$
(p F-p J g+w l c)^{\cdot}-r \dot{K}-w(L s+l c)^{\cdot}+\varepsilon(\pi g)^{\cdot} .
$$

We have assumed that the labor and balance of payment constraints are binding. ${ }^{2}$ Differentiating products, rearranging terms, and using the second dual constraint and the definition of $\mathrm{F}$ presented in the primal program

$$
\begin{aligned}
& p \dot{F}-r \dot{K}-w(L s)^{\cdot} \\
& -p J \dot{g}+\varepsilon(\pi g)^{\cdot} \\
& +\dot{p}(F-J g)+(w l c)^{\cdot}-w(l c)^{\cdot} \\
& = \\
& p \dot{F}-r \dot{K}-w(L s)^{.} \\
& +\varepsilon \dot{\pi} g \\
& +\dot{p} f c+\dot{w} l c .
\end{aligned}
$$

The first term is the technical change effect or Solow residual (SR). It corresponds to the numerator of the traditional Solow residual, except that here it is evaluated at shadow commodity prices and optimal sectoral activity levels. The second term, $\varepsilon \dot{\pi} g$, is the terms of trade effect. Proportional changes in $\pi$ are offset by a change in $\varepsilon$. Only relative international price changes matter. The last two terms are the demand effect (Wolff, 1985). By the remark, $p f+w l$ may be held constant, so that the demand effect reads $-(p \dot{f}+w i) c$. If demand $(f, l)$ shifts to commodities with low opportunity costs, it is relatively easy to satisfy domestic final demand and TFP gets a boost. The terms of trade and demand effects disappear when there is only one commodity and no non-business labor. Under these circumstances, $\pi$ is unity and $p$ also by the second dual constraint, hence their derivatives vanish. In other words, in a macro-economic setting TFP-growth reduces to the Solow residual. It should be mentioned, however, that a tiny difference remains in the denominators. We divide

\footnotetext{
${ }^{2}$ If the labor and balance of payment constraints are not binding, an additional term should enter the TFP-growth decomposition, containing the changes in the slacks of those constraints..
} 
by $p f c+w l c=p F-p J g+w l c=p F-\varepsilon \pi g+w l c=p F+\varepsilon D+w l c$. In other words, we account for the deficit and non-business labor income.

Examples. In three examples we will highlight the technical change, terms of trade, and taste components of TFP-growth. The first two examples feature no trade, but ascribe all TFP-growth to either the Solow residual or the taste effect. The third example illustrates the terms of trade effect. The examples differ by end situation. The base situation is always an economy with labor inputs $L=\left(\frac{4}{3} \frac{2}{3}\right)$ and commodity outputs $V=I$. There is no trade, capital, intermediate inputs, or unemployed labor.

In the first example, labor employment remains the same, but output shifts from commodity 2 to commodity 1 , so that $V$ turns $\left(\begin{array}{cc}1+\varepsilon & 0 \\ 0 & 1-\varepsilon\end{array}\right)$. The solution to the primal program was and is $2 * 1=2$. By the macro-economic identity $w$ was and is 1 . Hence TFP-growth is zero. There is technical change, however, for output has shifted towards the resource intensive commodity, stepping outside the initial production possibility frontier. The Solow residual is $p \dot{F}=\left(\begin{array}{ll}\frac{4}{3} & \frac{2}{3}\end{array}\right)\left(\begin{array}{c}+\varepsilon \\ -\varepsilon\end{array}\right)=\frac{2}{3} \varepsilon$. The new demand is unfavorable. The demand effect is $\dot{p} f c$. The price vector turns $\left(\frac{4 / 3}{1+\varepsilon} \frac{2 / 3}{1-\varepsilon}\right)$ and has derivative $\left(\begin{array}{ll}-\frac{4}{3} \varepsilon & \frac{2}{3} \varepsilon\end{array}\right)$ (for $\varepsilon$ small), so that the demand effect is $\left(\begin{array}{ll}-\frac{4}{3} \varepsilon & \frac{2}{3} \varepsilon\end{array}\right)\left(\begin{array}{l}1 \\ 1\end{array}\right)$ (for $\varepsilon$ small) or $-\frac{2}{3} \varepsilon$.

The second example is similar, but now $V$ turns $\left(\begin{array}{cc}1-\varepsilon & 0 \\ 0 & 1+2 \varepsilon\end{array}\right)$. The solution to the primal program becomes $(1-\varepsilon+1+2 \varepsilon) * 1=2+\varepsilon$ and the wage rate becomes $1+\frac{\varepsilon}{2}$. The gain has to be multiplied by the number of worker, yielding TFP-growth of $\varepsilon$. It can be ascribed entirely to the taste effect, for the economy shifts along its frontier, foregoing $\varepsilon$ of the doubly labor intensive commodity, nr. 1 , for $2 \varepsilon$ of commodity nr. 
In the third example, world prices ( $\left.\begin{array}{ll}1 & 1\end{array}\right)$ turn $(1+\varepsilon 1-\varepsilon)$, while $L$ and $V$ remain the same. The linear program expands the domestic consumption vector, $\left(\begin{array}{l}1 \\ 1\end{array}\right)$, by letting the economy specialize in the resource extensive commodity, nr. 2. Output is the same before and after the international price change, but the terms of trade detiorate, reducing the level of consumption and, therefore, the real wage rate and TFP.

\section{Remarks}

1. The TFP measure used in Mohnen, ten Raa and Bourque (1997) is confined to the Solow residual without the terms of trade and taste effects. There is also a slight normalization difference. In this paper, we normalize with respect to $r K+w N+\varepsilon D=p f c+w l c$, whereas Mohnen, ten Raa and Bourque (1997) normalize with respect to $p F=p f c+p J g$. 2. Implicit to our model is the assumption of Leontief preferences over domestic final demand. Retail and banking services are components of the domestic final demand vector. In a way, one might argue that households favor reductions of these components. The smaller the margins, the more efficient the economy. This effect is captured by the demand effect component of TFP-growth. Factor productivity gains within these service sectors are captured by the Solow residual.

3. In discrete time, the differentials are approximated using the identity $x_{t} y_{t}-x_{t-1} y_{t-1}=\widehat{x_{t}} \overline{x_{t} y_{t}}+\widehat{y_{t}} \overline{x_{t} y_{t}}$, where $\widehat{x_{t}}=\left(x_{t}-x_{t-1}\right) / \overline{x_{t}}$ and $\overline{x_{t}}=\left(x_{t}+x_{t-1}\right) / 2$, and similarly for $\widehat{y_{t}}$ and $\overline{y_{t}}$.

Disaggregation. By Domar's aggregation we can decompose the aggregate Solow residual into sectoral and group-sectoral Solow residuals. Let $\mathrm{j}$ index the sectors, $\mathrm{i}$ the commodities, and $\mathrm{k}$ the sector groups. Define the Solow residual of group-sector $\mathrm{k}$ as: 


$$
\begin{aligned}
S R_{k} & =\frac{\sum_{j \in k} \sum_{i} p_{i} v_{j i} s_{j}\left(v_{j i} / v_{j i}\right)}{\sum_{j \in k} \sum_{i} p_{i} v_{j i} s_{j}}-\frac{\sum_{j \in k} \sum_{i} p_{i} u_{i j} s_{j}\left(u_{i j} / u_{j i}\right)}{\sum_{j \in k} \sum_{i} p_{i} v_{j i} s_{j}} \\
& -\frac{\sum_{j \in k} w L_{j} s_{j}\left(L_{j} / L_{j}\right)}{\sum_{j \in k} \sum_{i} p_{i} v_{j i} s_{j}}-\frac{\sum_{j \in k} r_{j} c_{j} K_{j} s_{j}\left(c_{j} K_{j}\right)^{\prime} / c_{j} K_{j}}{\sum_{j \in k} \sum_{i} p_{i} v_{j i} s_{j}}
\end{aligned}
$$

Notice that if $k=j$, we get the Solow residual for sector $j$. It can be shown that our aggregate Solow residual $(S R)$ expression can be written as:

$$
S R=\frac{\sum_{k} \sum_{j \in k} \sum_{i} p_{i} v_{j i} s_{j}}{\sum_{i} p_{i} F_{i}} S R_{k}
$$

\section{Data}

We use the input-output tables of the Canadian economy from 1962 to 1991 at the medium level of disaggregation, which has 50 industries and 94 commodities.

The constant price input-output tables have been obtained from Statistics Canada in 1961 prices from 1962 to 1971, in 1971 prices from 1971 to 1981, in 1981 prices from 1981 to 1986, and in 1986 prices from 1986 to 1991. All tables have been converted to 1986 prices using the chain rule. For reasons of confidentiality, the tables contain missing cells, which we have filled using the following procedure. The vertical and horizontal sums in the make and use tables are compared with the reported line and column totals, which do contain the missing values. We select the rows and columns where the two figures differ by more than $5 \%$ from the reported totals, or where the difference exceeds $\$ 250$ million. We then fill holes or adjust cells on a case by case basis filling in priority the intersections of the selected rows and columns, using the information on 
the input or output structure from other years, and making sure the new computed totals do not exceed the reported ones.

The gross capital stock, hours worked and labor earnings data are from the KLEMS dataset of Statistics Canada, described in Johnson (1994). In particular, corrections have been made to include in labor the earnings of the self-employed, and to separate business and non-business labor and capital. The total labor force figures are taken from Cansim (D767870) and converted in hours using the number of weekly hours worked in manufacturing (where it is the highest). Out of the 50 industries, no labor nor capital stock data exist for sectors $39,40,48,49,50$, and no capital stock data for industry 46 .

The sectoral capacity utilization rates have been provided by the National Wealth and Capital Stock Division of Statistics Canada. They have been constructed using the Hodrick-Preston filter. For agriculture and fishing, we use the utilization rate for food. For all the service sectors, except construction, pipeline transportation, and power and gas distribution, we use the rate for total non-farm goods (excluding energy) producing industries, the most encompassing capacity utilization rate available.

The international commodity prices are approximated by the U.S. prices, given that $70 \%$ of Canada's trade is with the United States. We have used the U.S. producer prices from the U.S. Bureau of Labor Statistics, Office of Employment Projection. The 169 commodity classification has been bridged to Statistics Canada's 94 commodity classification. To convert U.S. prices to Canadian equivalents, we have used, whenever available, unit value ratios, (UVRs, which are industry specific) computed and kindly provided to us by Gjalt de Jong (1996). The UVRs are computed using Canadian quantities valued at U.S. prices. For the other commodities, we have used the purchasing power parities computed by the OECD (which are based on final demand categories). The 
UVRs establish international price linkages for 1987, the PPPs for 1990 in terms of Canadian dollars per U.S. dollar. We hence need two more transformations. First, U.S. dollars are converted to Canadian dollars using the exchange rates taken from Cansim (series 0926/B3400). Second, since the input-output data are in 1986 prices, we need the linkage for 1986, which is computed by using the respective countries' commodity deflators: the producer price index for the U.S. (see above) and the total commodity deflator from the make table (except for commodities 27, 93 and 94, for which we use the import deflator from the final demand table) for Canada.

Are considered as non-tradeable, commodities 13, 44, 70, 71, 72, 79, 81, $82,88,91$ and 92 , for which no trade shows up in the input-output tables for most of the sample period.

For computational reasons and similar output composition, we have aggregated the nontradeable commodities 70-72 (residential, nonresidential and repair construction). Due to the absence of labor,capital stock and intermediate inputs for industry 39 (government royalties on natural resources), it has been aggregated with industry 5 (crude petroleum and natural gas). In the end, we are thus left with 49 industries and 92 commodities, which are listed in tables 1 and 2. A more detailed documentation of the data and their construction is available from the authors upon request.

\section{Results}

Perhaps it is most illuminating to discuss the temporally aggregated results first. In table 3 we have productivity growth figures obtained using endogenous weights, i.e. evaluated at the shadow prices and optimal activity levels of the linear program. Table 3 shows a $1.60 \%$ annual TFP-growth rate over the 1962-75 period. ${ }^{3}$ Over the next business cy-

\footnotetext{
${ }^{3}$ According to Bergeron, Fauvel and Paquet (1995), Canada hit a recession from January 1975 to March 1975, from May 1980 to June 1980, from August 1981 to
} 
cle (1976-82), TFP-growth fell to $-3.83 \%$. It recovered to $-0.47 \%$ per annum in the 1980's (1982-91). The demand effect was nearly zero in the first period and positive in the subsequent periods. Consumers apparently switched their patterns of demand towards commodity bundles with lower contents of expensive factors. The technical change effect explained the lion's share of TFP-growth: the Solow residual fell far below zero after 1975, but then recovered in the $80 \mathrm{~s}$. The terms of trade effect played a minor role and followed a similar pattern as technical change. At the optimal terms of trade and trade balance, relative world prices moved so as to increase our purchasing power before 1970 and to decrease it afterwards. The three effects add up to TFP-growth.

From its definition, TFP-growth can also be decomposed into its constituent marginal productivity growth rates. We then get a second accounting identity. However, we think it is more informative to present the absolute marginal productivity growth rates without their weights in TFP-growth. We see that labor productivity declined on average by $0.22 \%$ par year in $1962-75$ and by $1.26 \%$ per year in $1983-91$. During the turbulent period of the oil shocks (1976-82), it actually increased on average by a strong $9.36 \%$ per annum. Capital productivity growth followed the same pattern as TFP-growth, reflecting the predominant value of capital, and as we shall see later of a particular type of capital, in the value of output. The productivity of the trade deficit, i.e. the increased consumption permitted by a marginal increase in the allowed deficit, declined all the time.

The main culprit of low aggregate TFP-growth performance is the construction sector. It explains the dramatic downturn in the 1970s as well as the sluggish productivity growth performance throughout the 1980s. It produces a non-tradeable commodity which acts as a bottleneck to the

November 1982, and from April 1990 to March 1991. We therefore chose the slump years 1975, 1982 and 1991 to compare productivity performances over a business cycle. These years also displayed low rates of capacity utilization for non-farm goods producing industries. 
outward shift of the production possibility frontier. Hence the shadow price of the capital stock in construction is high, and therefore this sector carries a lot of weight. The analysis suggests that if construction was opened to U.S. activity, the production possibility frontier would be pushed out and TFP levels would be increased. Although they do not carry much weight, business and personal services always had deplorable productivity growth rates. They might suffer from the Baumol disease.

Transportation has consistently outperformed manufacturing in the Solow residual, so has communication until 1982. Trade has exhibited a strong productivity performance except during the 1976-82 period and FIRE is becoming the success story of the 90s. Its Solow residual is second only to the primary sector, which recovers from a disastrous performance in the late 70s. Thus not all service sectors have low TFP growth rates.

Tables 4 lists the annual productivity growth figures giving a more precise timing of the up- and downturns of productivity growth. As is well known and also very apparent here, TFP-growth fluctuates a lot. Nonetheless, the primary sector, B\&P services, construction, as well as FIRE until 1974 and communication since 1978, display negative Solow residuals most of the time. Manufacturing has the least variation in the Solow residual. Transportation and trade have been driving forces. The productivity in communication is slipping, whereas FIRE is a recent success story. There is only instance (1983-1984) in which every group of sectors experienced positive Solow residuals. There are more occurences of negative Solow residuals in the second half than in the first half of our sample period.

Table 5 gives an account of the evolution of the shadow rates of return on capital and wage rate. Construction often acts as a bottleneck and reaps enormous rewards. In some years, the returns on capital in construction fade away and get spread out over the other industries, often trade earns 
the highest returns. These huge returns imply heavy weights attached to the marginal productivities of capital in TFP-growth. Therefore in table 3, TFP-growth mimicks the evolution of capital productivity. In one year (1978), labour was so abundant relative to capital to earn a zero marginal return. This explains why in table 4, the labor-intensive $\mathrm{B} \& \mathrm{P}$ services show wide fluctuations in the Solow residual in the two pairs of years adjacent to 1978 .

We have checked the sensitivity of our results to the use of net instead of gross capital stocks. The solutions to the linear programs are unaffected, so are the optimal shadow wage rates. The only difference is in the shadow prices of capital, which adjust to the new capital stock measures so as to yield zero profit conditions. It is like a scaling problem. All that matters in our model for the expansion to the efficiency frontier are the rates of capacity utilization. The choice of measurement for the capital stocks would only matter if capital from various sectors was substitutable. TFP-growth rates differ because the marginal productivities of capital differ. But both qualitatively and quantitatively, the results are rather similar.

\section{Conclusions and qualifications}

Annual TFP growth was positive on average over the 1960-75 period. It dropped quite sharply during the 1976-82 interval and recovered, but not to the levels of the golden sixties, after 1982. This finding confirms

conventional wisdom. Our productivity figures show greater fluctuations than what is usually reported, because they are extracted endogenously from a linear program with corner solutions. Of course, our methodology differs from conventional productivity analysis in one major respect. We compute in some sense social productivities, i.e. marginal valuations of inputs in terms of attainable total domestic consumption and not in terms of attainable individual sectoral production. We take the whole economy into account globally, with its interdependencies and mutual 
constraints, to derive the efficient production frontier and define productivity growth as the outward shift of that efficiency frontier rather than changes in observed input-output ratios.

Our model offers some explanation to productivity growth. Some inputs can earn high returns if they are in short supply. TFP-growth is nothing but a reflection of the evolution of marginal valuations of primary factor inputs. The modeling of existing constraints is very crucial in our approach. Our computed aggregate TFP-growth rates are to a large extent explained by the bottelneck in construction. Perhaps the hypothesis of putty-clay capital in that low capital-intensive sector was overly restrictive. Another key role in our analysis is played by the levels of capacity utilization. Their construction is still controversial. No estimates are available for services. Proper measures of output and capacity utilization for services are problematic, but we urge Statistics Canada to devote resources to construct such measures. Our analysis would also be enriched if we could have data on sectoral use and total availability of labor disaggregated by level of qualification and of sectoral utilization and availability of capital disaggregated by type of capital. It would allow us to get a more precise picture of scarcities in the Canadian economy. By construction, the vintage structure of capital does not matter. To relax this assumption, we would need to make investment endogenous and switch to a dynamic model, which would lead to Hulten's notion of a dynamic residual.

Despite these words of caution about the interpretation of our results, our analysis reveals some interesting insights into the productivity of Canadian services. Apart from construction and business and personal services, the other service sectors have performed remarkably well compared to manufacturing. There is no productivity paradox in trade, and finance, insurance and real estate. Only transportation and communication show a trended deceleration in their Solow residuals. But their productivity growth was high until the beginning of the 80 s. The com- 
monly held view that services are dragging down the whole economy does not stand the facts. 


\section{References}

Bergeron, L., Y. Fauvel et A. Paquet (1995), "L'indicateur synthétique avancé de l'économie canadienne selon la méthode de Stock et Watson", mimeo, Centre de recherche de l'emploi et des fluctuations économiques, UQAM.

de Jong, G. (1996), "Canada's Postwar Manufacturing Performance: A Comparison with the United States", Research Memorandum, Groningen Growth and Development Center, GD-32.

Hall, R. (1990), "Invariance Properties of Solow's Residual", in Growth/Productivity/Employment, P. Diamond (ed.), 71-112, MIT Press, Cambridge, MA.

Johnson, J. (1994), "Une base de données KLEMS décrivant la structure des entrées de l'industrie canadienne", Statistique Canada, Division des Entrées-Sorties, Cahier Technique \#73F.

Jorgenson, D. and Z. Griliches (1967), "The Explanation of Productivity Change", Review of Economic Studies, 34(3), 308-350.

Mohnen, P., T. ten Raa and G. Bourque (1997), "Mesures de la croissance de la productivité dans un cadre d'équilibre général: L'économie du Québec entre 1978 et 1984", Canadian Journal of Economics, 30(2), forthcoming.

Solow R. (1957), "Technical Change and the Aggregate Production Function", Review of Economics and Statistics, 39(3), 312-320.

ten Raa, T. (1995), Linear Analysis of Competitive Economies. LSE Handbooks in Economics, Harvester Wheatsheaf, New York.

Weitzman, W. (1976), "On the Welfare Significance of National Product in a Dynamic Economy," Quarterly Journal of Economics 90, 156-162. 
Wolff, E. (1985), "Industrial Composition, Interindustry Effects, and the U.S. Productivity Slowdown", Review of Economics and Statistics, 67, 268-77. 


\section{Liste des publications au CIRANO .}

\section{Cahiers CIRANO / CIRANO Papers (ISSN 1198-8169)}

96c-1 Peut-on créer des emplois en réglementant le temps de travail ? / Robert Lacroix

95c-2 Anomalies de marché et sélection des titres au Canada / Richard Guay, Jean-François L'Her et Jean-Marc Suret

95c-1 La réglementation incitative / Marcel Boyer

94c-3 L'importance relative des gouvernements : causes, conséquences et organisations alternative / Claude Montmarquette

94c-2 Commercial Bankruptcy and Financial Reorganization in Canada / Jocelyn Martel

94c-1 Faire ou faire faire : La perspective de l'économie des organisations / Michel Patry

Série Scientifique / Scientific Series (ISSN 1198-8177)

97s-37 A General Equilibrium Analysis of the Evolution of the Canadian Service Productivity / Pierre Mohnen et Thijs ten Raa

97s-36 Moving towards the Virtual Economy: A Major Paradigm Shift / Louis A. Lefebvre et Élisabeth Lefebvre

97s-35 Seasonal Time Series and Autocorrelation Function Estimation / Hahn Shik Lee, Eric Ghysels et William R. Bell

97s-34 Do Canadian Firms Respond to Fiscal Incentives to Research and Development? / Marcel Dagenais, Pierre Mohnen et Pierre Therrien

97s-33 A Semi-Parametric Factor Model of Interest Rates and Tests of the Affine Term Structure / Eric Ghysels et Serena Ng

97s-32 Emerging Environmental Problems, Irreversible Remedies, and Myopia in a Two Country Setup / Marcel Boyer, Pierre Lasserre et Michel Moreaux

97s-31 On the Elasticity of Effort for Piece Rates: Evidence from the British Columbia Tree-Planting Industry / Harry J. Paarsch et Bruce S. Shearer

97s-30 Taxation or Regulation: Looking for a Good Anti-Smoking Policy / Paul Leclair et Paul Lanoie

97s-29 Optimal Trading Mechanisms with Ex Ante Unidentified Traders / Hu Lu et Jacques Robert

97s-28 Are Underground Workers More Likely To Be Underground Consumers? / Bernard Fortin, Guy Lacroix et Claude Montmarquette

97s-27 Analyse des rapports entre donneurs d'ordres et sous-traitants de l'industrie aérospatiale nord-américaine / Mario Bourgault

\footnotetext{
* Vous pouvez consulter la liste complète des publications du CIRANO et les publications elles-mêmes sur notre site World Wide Web à l'adresse suivante :

http://www.cirano.umontreal.ca/publication/page1.html
} 